\title{
Cladocera paleocommunity to disentangle the impact of anthropogenic and climatic stressors on a deep subalpine lake ecosystem (Lake Iseo, Italy)
}

\author{
Barbara Leoni (iD $\cdot$ Martina Patelli $\cdot$ Veronica Nava $\cdot$ Monica Tolotti
}

Received: 12 January 2021 / Accepted: 1 March 2021 / Published online: 12 March 2021

(C) The Author(s) 2021

\begin{abstract}
In big lakes with strong anthropogenic pressure, it is usually difficult to disentangle the impacts of climate variability from those driven by eutrophication. The present work aimed at the reconstruction of change in the species distribution and density of subfossil Cladocera in Lake Iseo (Italy) in relation to climate and anthropogenic pressure. We related subfossil Cladocera species composition and density in an $80-\mathrm{cm}$ sediment core collected in the pelagic zone of Lake Iseo to long-term temperature trends and phosphorus concentration inferred by diatoms frustules. The Cladocera remains detected in Lake Iseo sediment reflected the species composition and density of modern pelagic Cladocera assemblages. Cladocera rapidly respond to environmental change, and that climate change combined with eutrophication can induce changes in community composition and species density. At the beginning of twentieth century,
\end{abstract}

Handling Editor: Télesphore Sime-Ngando.

B. Leoni $(\bowtie) \cdot$ M. Patelli · V. Nava

Department of Earth and Environmental Sciences,

University of Milano-Bicocca, Piazza della Scienza 1,

20126 Milan, Italy

e-mail: barbara.leoni@unimib.it

M. Tolotti

Department of Sustainable Agro-Ecosystems and

Bioresources, Research and Innovation Centre, Edmund

Mach Foundation (FEM), Via E. Mach 1,

38010 San Michele all'Adige, Italy when global warming was not yet so accentuated, the nutrient increase in water resulted as the principal driver in determining the long-term development of plankton communities and pelagic food web structure. Moreover, catchment-related processes may decisively affect both species composition and density of the lake planktonic communities due to the decrease of lake water transparency induced by input of inorganic material from the catchment area to the lake. The paleolimnological investigation, through the combined study of biotic and abiotic factor, allowed clarifying the synergic effects of the most important drivers of change in lake ecosystems, suggesting that climatic factors should be considered with nutrient availability as determinant element in controlling the temporal development of plankton communities and pelagic food web structure.

Keywords Zooplankton P Paleolimnology $\cdot$ Multiple stressors · Environmental change - Sediments · Eutrophication

\section{Introduction}

Multiple anthropogenic and natural stressors can compromise lake ecological quality and ecosystems services. Although it is widely accepted that eutrophication is still one of the most impacting problems for 
lake water quality, in the last decades, it has become evident that also climate change can strongly influence lake ecosystem and lake water quality (Adrian et al. 2009; Perga et al. 2015). In deep lakes affected by multiple and strong anthropogenic pressures, it is usually difficult to disentangle the impacts driven by climate from that driven by eutrophication, as these impacts may often produce additive or synergic effects on lake ecology.

Cladocera (Crustacea) are key organisms in the pelagic food web of deep lakes, as they represent the link between bottom-up factors (nutrient and phytoplankton) and top-down regulators (fish and other invertebrate predators) (Leoni 2017). Moreover, zooplanktonic organisms are particularly sensitive to environmental stressors, such as climate change and nutrient variations (Vadadi-Fülöp and Hufnagel 2014). The chitinous bodies of Cladocera organisms can be well preserved in lake sediments and present some typical morphological characteristics useful for the identification at species level. Therefore, they are considered to be a good proxy for reconstructing lake responses to environmental changes (Zawisza and Szeroczyńska 2007; Alric et al. 2013; Cheng et al. 2020) and they have been widely used to track historical changes in lake either alone or in combination with other paleolimnological proxies (Tolotti et al. 2016; Caballero et al. 2020). Recent studies highlighted that the best way to track different aspects of past ecological responses to overlapping stressor is the multi-proxy approach, combining the analysis of paleolimnological biotic (e.g., subfossil cladoceran and diatoms frustules) and abiotic (e.g., inorganic and organic content) proxies and measured long-term data (e.g., air temperature, teleconnection indices) (Milan et al. 2015; Perga et al. 2015; Tolotti et al. 2018). Furthermore, sediment records can be useful to disentangle the effects of climate change and nutrient enrichment in deep lakes, because they span over secular time periods, that reach the time before the beginning of major human disturbance (Battarbee et al. 2012; Milecka et al 2020) and to help predicting future scenarios through the "past-forward" principle (Tolotti et al. 2018). Indeed, the present environmental and socioeconomic context makes the need for better capacity to predict future lake development increasingly urgent, especially in relation to the crucial need to understand the role of superimposed climate variability in modulating lake response to nutrients (Tolotti et al. 2018).

Surprisingly, the information on past lake trophic status and definition lake reference conditions for deep lakes of perialpine districts, with the exception of the Savoyan lakes, are far away from being exhausted and could be further exploited to address modern ecological and management issues, as well as lake changes in hydrology, thermal regime and biodiversity related to present climate variability (Tolotti et al. 2018).

The present work aims at reconstructing changes in the species composition and density of subfossil Cladocera in eutrophic Lake Iseo (the fourth largest lake in Italy) in relation to combined eutrophication and climate change. In order to study the effects of these stressors on lake biological communities, we relate subfossil Cladocera recorded in an $80-\mathrm{cm}$ sediment core, collected in the pelagic zone of Lake Iseo, to measured air temperature trends, climatic proxies, such as teleconnection indices, and nutrients, mainly phosphorus concentration inferred by diatoms frustules.

We strive to: (1) highlight long-term differences in Cladocera species composition and density along a century; (2) relate possible changes to historical limnological and climatic variability; and (3) discriminate between the lake's responses to nutrient enrichment and climate change through the comparison between Cladocera results and data from other sediment biological proxies (i.e., sediment organic content, diatom-inferred lake TP concentrations).

Lake Iseo appeared to be an ideal site to conduct this kind of paleolimnological investigation thanks to the high sedimentation rate due to the high ratio between catchment area and lake surface area (Leoni et al. 2019). Moreover, on Lake Iseo a monitoring limnological campaign has been carried out since the beginning of 1990s and this allows the interpretation and comparison of paleolimnological results in light of those provided by the decadal freshwater investigations.

\section{Methods}

Study area

Lake Iseo (Site LTER_EU_IT_008 “Southern Alpine Lakes"; http://www.lter-europe.net) is located in 
northern Italy, in the Alpine foothills (190 m a.s.l.) at the lower end of a large populated prealpine valley (Val Camonica). The inflow and outflow of water in the lake are from the River Oglio. Lake Iseo has a surface area of $61.8 \mathrm{~km}^{2}$, water volume of $7.6 \mathrm{~km}^{3}$, a maximum depth of $258 \mathrm{~m}$ and an average depth of $124 \mathrm{~m}$ (Nava et al. 2017). The surface area of the watershed, including the lake, is $1842 \mathrm{~km}^{2}$, with a mean altitude of $1429 \mathrm{~m}$ a.s.l and a maximum of $3554 \mathrm{~m}$ a.s.l (Garibaldi et al. 2003). Water temperatures of deep subalpine lakes typically do not drop below $4{ }^{\circ} \mathrm{C}$, so they are commonly classified as "warm monomictic," as they are characterized by complete water circulation once a year in late winter and stable stratification from spring season (Leoni 2017). Nevertheless, due to the great depth of Lake Iseo, late winter vertical mixing occurs only during harsh and windy winters. During the last 25 years, complete winter mixing occurred only in 2005 and 2006, so the lake is to be regarded as holo-oligomictic.

Lake Iseo experienced a relatively rapid eutrophication process since the 1970s that was mainly attributed to nutrient loading from the inflows (Leoni et al. 2019). The increase in nutrient loadings brought the lake to a meso-eutrophic condition, as total phosphorus concentrations in the water column increased from approximately $60 \mu \mathrm{gP} / \mathrm{L}$ in the $1990 \mathrm{~s}$ to $80 \mu \mathrm{gP} / \mathrm{L}$ between 2006 and 2016 (Rogora et al. 2018).

The contemporary zooplankton is largely dominated by copepods, mainly Copidodiaptomus steweri, but Cladocera and rotifers are significantly abundant from spring to autumn (Leoni et al. 2019).

Sediment coring, chronology and lithological parameters

An 80 -cm-long sediment core was collected in the deepest point of Lake Iseo $\left(45^{\circ} 43^{\prime} 11^{\prime \prime} \mathrm{N} ; 10^{\circ} 03^{\prime} 46^{\prime \prime} \mathrm{E}\right)$ using a Kajak gravity corer (UWITC, Austria) in late June 2014. The core was vertically extruded and sliced in the laboratory: the first $30 \mathrm{~cm}$ of the core was sliced at $0.5 \mathrm{~cm}$ contiguous intervals, while from $31 \mathrm{~cm}$ to the bottom at $1 \mathrm{~cm}$ intervals. Sediment visual aspects, i.e., color and texture presence of macroscopic remains, were annotated during slicing. The core chronology, from the surface to $74 \mathrm{~cm}$, was established through radiometric analysis of ${ }^{210} \mathrm{~Pb}$ and ${ }^{137} \mathrm{Cs}$,
${ }^{226} \mathrm{Ra}$ and ${ }^{241} \mathrm{Am}$ (Appleby 2005) by Ensis Ltd. (University College London, UK).

For all the subsamples, we determined the wet density, water content (measured by drying the sediment at $105{ }^{\circ} \mathrm{C}$ for at least $12 \mathrm{~h}$ ) and the organic matter content (measured as Loss On Ignition-LOI) after heating the sample at $550{ }^{\circ} \mathrm{C}$ in a furnace for three hours (Heiri et al. 2001).

\section{Diatom-inferred phosphorus}

In order to analyze diatom frustules preserved in the sediment, around $0.75 \mathrm{~g}$ of wet sediment from each subsample was treated with $\mathrm{H}_{2} \mathrm{O}_{2}(30 \%)$ and $\mathrm{HCl}$ (10\%) according to standard procedures (Battarbee et al. 2001). The cleaned diatom suspensions were permanently mounted using Naphrax ${ }^{\circledR}$ resin (refraction index $=1.7$ ). For each slide, at least 500 valves were counted under a light microscope (Leica DM2500) at $1000 \times$ magnification and using Nomarski interference contrast. Lake total phosphorus concentrations were inferred based on diatom taxa reaching relative density of $0.5 \%$ in each sediment subsample (diatom-inferred total phosphorus-DiTP) using the Swiss-TP calibration set-including a set of low- to medium-altitude lakes mainly located in the Swiss Plateau (Lotter et al. 1998) - and a weightedaverage regression with inverse deshrinking (TP $\mathrm{CH}$ WA-INV). This calibration set was preferred over the others available for Europe (i.e., Central Europe, combined European, Northwest European) based on its capacity to provide better estimations of the lake TP concentrations determined since the beginning of the monitoring of Lake Iseo in the 1960s. In fact, the alternative calibrations set clearly underestimated both the maximum and present lake TP concentrations.

\section{Subfossil Cladocera}

Cladocera remains were analyzed in 72 of the 110 subsample sliced from the core. The samples have been treated in order to clean and concentrate the subfossil remains following the method described by Szeroczyńska et al. (2007). About $2.5 \mathrm{~cm}^{3}$ of wet sediment was heated in $\mathrm{KOH}(10 \%)$ and then treated with $\mathrm{HCl}(10 \%)$; after the treatment, the subsample was washed through a mesh of $35 \mu \mathrm{m}$ and concentrated in falcon tubes. One-two drops of a safranin- 
glycerol mixture were added to the cleaned subsamples in order to facilitate the identification of the remains under an optical microscope $(100 \times$ or $400 \times$ magnification). Taxonomical identification of Cladocera remains was based on Szeroczyńska and Sarmaja-Korjonen (2007). Cladocera remains (headshield, shell, postabdomen, postabdominal claw, mandible) were counted and converted to a number of individuals following Frey (1986). From three to six slides for each sample were counted in order to obtain a minimum of 100 individuals (Milan et al. 2016); however, this number had not been reached in a few samples characterized by very scarce density of remains.

\section{Data elaboration and analysis}

In order to detect general changes in Cladocera community, the total pelagic species density (Total Pelagic), the total littoral species density (Total Littoral) and the total Cladocera density (Total) were calculated. Additionally, the percentage of pelagic species above the total (Pelagic \%) was computed in order to detect the proportion between pelagic and littoral taxa.

Starting from sedimentation rates (provided by the radiometric dating) and the percent organic content of each sediment layer (LOI\%), the inorganic sedimentation rate (InSedRate) has been calculated. This parameter has been used as a proxy of the inorganic materials carried from the catchment area.

Homogenized monthly mean air temperatures provided by the HISTALP data set (Auer et al. 2007) for Torbole-Riva station (c.a. $60 \mathrm{~km}$ away from the coring point) were used as proxy for climate variability at Lake Iseo, covering the ages between 1908 and 2010. In particular, the average values of temperature from March to September (representing the vegetative period) and in winter season (December-February) have been calculated. The presence of significant trend in temperature data was evaluated using the nonparametric Mann-Kendall test, and the slope was estimated using the Sen's slope estimator. Similarly, average values of East Atlantic pattern (EA) from March to September and from December to February have been calculated for the ages 1950-2014. The values of the teleconnection index East Atlantic pattern (EA), computed by the National Oceanic and Atmospheric Administration-Climate Prediction
Centre (NOAA-CPC, www.cpc.ncep.noaa.gov), were considered to outline possible relations between ecological dynamics and global atmospheric circulation patterns. We choose to use East Atlantic pattern because several studies verified the effectiveness of this atmospheric mode of variability in representing meteoclimatic variation and the influence on limnological characteristic and zooplankton phenology in the deep subalpine lakes (Leoni et al. 2018a; Rogora et al. 2018).

A Pettitt test (Mallakpour and Villarini 2016) was performed on the total pelagic Cladocera density in order to detect changing points in Cladocera community development.

A Spearman correlation analysis was performed in order to explore relations between the principal Cladocera taxon density and to detect intra-species relation, and between the principal Cladocera taxon density and LOI\% and InSedRate aiming at clarifying the relations between the density and the load of organic and inorganic materials to the Lake Iseo ecosystem.

Performing several tests on the same set of data may result in an increased risk of type I statistical error, i.e., the rejection of the null hypothesis of no difference between the zooplankton taxa densities and/or core lithological variables due to mere chance. A high conservative approach to reduce the risk of type I errors is to adopt Bonferroni correction of significance of statistical tests (Rice 1989). However, there is no general consensus on the procedure of application of Bonferroni correction (Nakagawa 2004), partially because the application of this high conservative approach may lead to considerably reduced power of the tests and consequently to increased risk of type II statistical errors, whereby the null hypothesis being tested is unduly accepted (Nakagawa 2004). In addition, several studies on relationships between actual zooplankton predator and prey, as well as among actual limnological characteristics and zooplankton population development, supported the existence of many direct correlations between the tested parameters in this study. Considering the well-known relationships mentioned above and the absence of a clear theoretical framework for how to apply correction of significance to data of this nature, we decided to consider the uncorrected $p$ values $<0.05$ as significant. However, we have also applied a Bonferroni correction and we highlighted 
relationships that were significant according to this procedure.

The data analysis and environmental variable graphical elaboration have been performed with $\mathrm{R}$ (version 3.6.1), using the packages "base," "trend." The graphical elaboration of the stratigraphic data has been performed using the software $\mathrm{C} 2$ version 1.7.7 (Juggins 2007).

\section{Results}

Sediment core analysis

The ${ }^{210} \mathrm{~Pb}$ - and ${ }^{137} \mathrm{Cs}$-based core chronology spanned from $1922 \pm 13$ at depth $73.5 \mathrm{~cm}$ and 2014 on the surface with an average error of \pm 6 year. Sediment accumulation rate (Fig. 1a) presented an average value of $0.39 \mathrm{~g} / \mathrm{cm}^{2}$ year from the sediment top down to the beginning of the 1980 s, and then, it decreased under $0.2 \mathrm{~g} / \mathrm{cm}^{2}$ year, with the exception of two peaks over $0.5 \mathrm{~g} / \mathrm{cm}^{2}$ year in $1995 \pm 4$ and in $1998 \pm 3$.

Organic matter content presented as a percentage of LOI showed minimum values in the deeper layer of the core and gradually increased in the upper layer (Fig. 1b). The minimum and the maximum recorded values were, respectively, $4.2 \%$ at $76.5 \mathrm{~cm}$ depth and $18.5 \%$ at $16.75 \mathrm{~cm}$. In the upper layers, from the beginning of 1980s until 2014, it was possible to observe a particularly accentuated variability, with values spanning from $8.8 \%$ to $18.5 \%$.

Diatom-inferred total phosphorus

Subfossil diatoms (Tolotti, unpublished data) are characterized by the dominance of planktonic taxa through the whole sediment core and by a pronounced dominance up to $80 \%$ of the total diatom density of the oligotraphentic Cyclotella comensis group from the beginning of the twentieth century until the early 1940s, when colony-forming pennate taxa
Fig. 1 Parameters scaled by depth from the sediment core taken within Lake Iseo: a sedimentation rate; b percentage of loss on ignition (LOI\%); c phosphorus inferred by diatoms (DiTP)

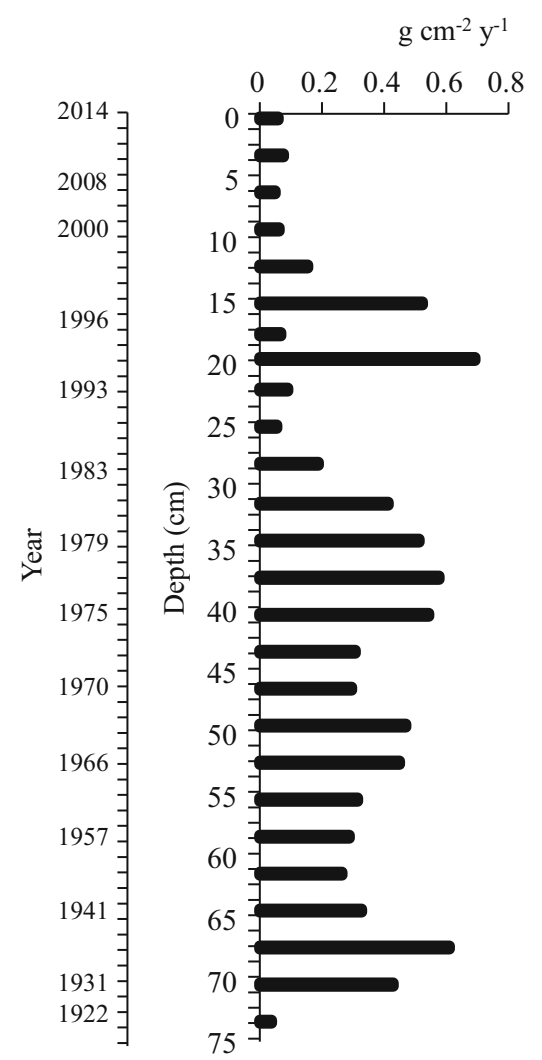

(a) Sedimentation rate

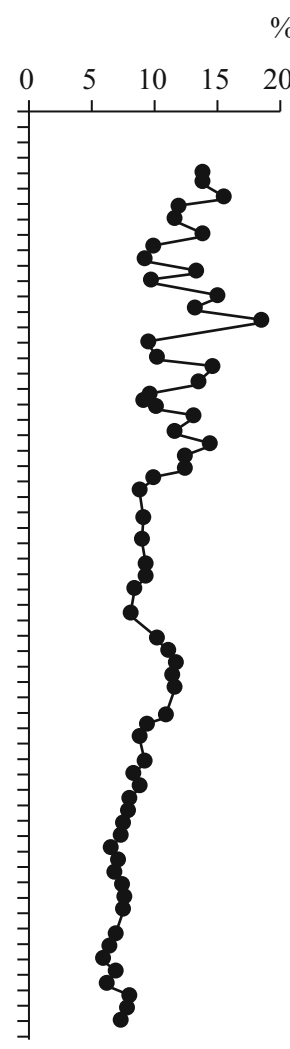

(b) LOI $\mu g \mathrm{~L}^{-1}$

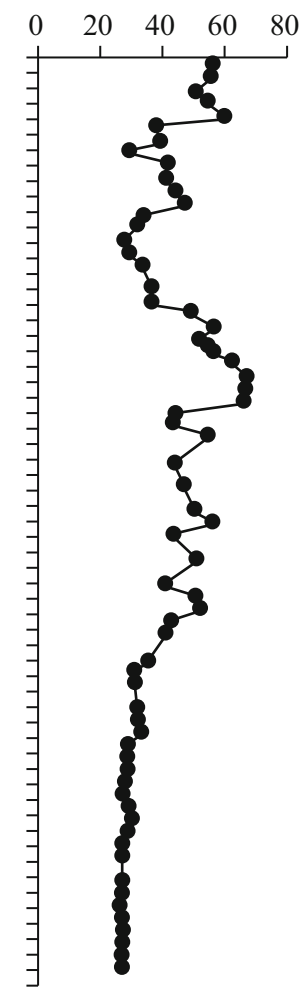

(c) DiTP 
Asterionella formosa and Fragilaria crotonensis started to increase. These meso-traphentic taxa reached their highest density in the first half of the 1980s, when they were accompanied by eutraphentic taxa, such as Stephanodiscus parvus. The proportion of C. comensis partially recovered in the 1990s, while the sediment layers deposited since the early 2000s show a new increase of the meso- and eutraphentic taxa. The values of total phosphorus inferred by diatoms largely reflect this taxonomic alternation and present an increasing trend from the deeper to the surface layers (Fig. 1c). In particular, a constant total phosphorus concentration of $28 \mu \mathrm{gP} / \mathrm{L}$ was estimated from the core bottom until $48.5 \mathrm{~cm}$ (year $1968 \pm 7$ ). From 48.5 to $20.5 \mathrm{~cm}$, the total phosphorus concentration increased, reaching a maximum of $67 \mu \mathrm{g} / \mathrm{L}$ at $25.75 \mathrm{~cm}$ (year $1993 \pm 4$ ). In the surface layers, i.e., from 25.75 until the core surface, total phosphorus variability was quite high spanning from a minimum of $28 \mu \mathrm{gP} / \mathrm{L}$ at $14.75 \mathrm{~cm}$ (year $1998 \pm 3$ ) to a maximum concentration of $62 \mu \mathrm{gP} / \mathrm{L}$ at $24.5 \mathrm{~cm}$ (year $1989 \pm 6)$.

\section{Subfossil Cladocera remains}

The subfossil Cladocera assemblage of Lake Iseo sediment core featured 29 taxa (Table 1), including 8 pelagic and 21 littoral taxa. The identified taxa belonged to the families Leptodoridae, Daphniidae, Bosminidae, Cercopagidae and Chydoridae. The Cladocera belonging to the first four families consist of open water zooplankton (pelagic), while taxa belonging to Chydoridae are characteristic of the littoral zone. The Cladocera densities are presented in Figs. 2 and 3; in the last, nine littoral and two pelagic species are not represented as they were detected in only one sediment level each and with scarce density. The pelagic species prevailed over littoral ones and represented for most of the layers the total density, while only in the layers deeper than $61.5 \mathrm{~cm}$ (year $1950 \pm 10$ ) pelagic species were less than $50 \%$ of the total remains. The Cladocera density was particularly low in the deeper layers of the core, from 79.5 to $64.5 \mathrm{~cm}$ depth, that were deposited from the early twentieth century until $1941 \pm 12$, while are quite swinging in the upper layer but considerably higher.

A Pettit test applied on the total of the pelagic species pointed out three significant changing points in the pelagic density, in $1941 \pm 12$ years
( $p$ value $<0.001)$, in $1969 \pm 8$ years ( $p$ value $<0.001)$ and in $1993 \pm 4$ years $(p$ value $<0.05)$.

The first section (Figs. 2 and 3-zone 1), from 79.5 to $64.5 \mathrm{~cm}$, was characterized by scarce Cladocera density and a number of taxa spanning from 1 to 5 per layer. The most relevant among the pelagic are Bosmina (Eubosmina) longispina group (from here on out B. longispina), Bosmina (Bosmina) longirostris (from here on out B. longirostris), Daphnia longispina group (from here on out D. longispina) and the zooplanktivorous Bythotrephes longimanus (Fig. 3). The second section (Figs. 2 and 3-zone 2), from 64.5 to $48.5 \mathrm{~cm}$, showed higher density of both pelagic and littoral taxa and higher species variability. In particular, B. longispina and the littoral species Chydorus sphaericus and Graptoleberis testudinaria appeared here for the first time. The third section (Figs. 2 and 3-zone 3), from 48.5 to $21.75 \mathrm{~cm}$, was characterized by swinging density, as the pelagic species prevailed in some layers while in others prevailed the littoral ones. It was possible to observe two peaks, i.e., 19,000 ind/g DW and 16,000 ind/g DW, respectively, in pelagic species density at 45.5 and at $27.75 \mathrm{~cm}$, corresponding to years $1971 \pm 7$ and $1984 \pm 4$, respectively (Fig. 3). Conversely, at 36.5-cm depth it was possible to observe a general decline in the identified subfossil Cladocera remains, with a total density of $91 \mathrm{ind} / \mathrm{g}$ DW. The high density of the pelagic species was particularly due to Bosmina (Eubosmina) spp., D. longispina group and the two zooplanktivorous B. longimanus and Leptodora kindti (Fig. 3). On the contrary, C. sphaericus resulted as the most abundant littoral taxa. The most recent core section (Figs. 2 and 3-zone 4), from $21.75 \mathrm{~cm}$ to the core surface, is characterized by the prevalence of pelagic species that represented more than $95 \%$ of the total density (Fig. 2-zone 4). However, periods of high Cladocera density alternated with phases characterized from lower levels, with a minimum of 393 $\mathrm{ind} / \mathrm{g} \mathrm{DW}$ at $18.5 \mathrm{~cm}(1995 \pm 4)$ and a maximum of $16,900 \mathrm{ind} / \mathrm{g} \mathrm{DW}$ at $0.5 \mathrm{~cm}$ (2014). In this core section, it was possible to observe the increase in Bosmina (Eubosmina) coregoni group (Baird, 1857) (from here on out $B$. coregoni) density and a decreased density of $B$. longirostris, the latter being identified only in six layers (Fig. 3-zone 4). Included in the most abundant pelagic species there were also $B$. longimanus, L. kindti and D. longispina. 
Table 1 List of all taxa identified in the core with indication of authority and habitat (based on Szeroczyńska and SarmajaKorjonen 2007)

\begin{tabular}{|c|c|c|c|}
\hline $\mathrm{N}$ & Taxon name & Authority & Habitat \\
\hline 1 & Acroperus harpae & (Baird, 1835) & Littoral \\
\hline 2 & Alona affinis & (Leydig, 1860) & Littoral \\
\hline 3 & Alona costata & Sars. 1862 & Littoral \\
\hline 4 & Alona guttata & Sars. 1862 & Littoral \\
\hline 5 & Alona intermedia & Sars. 1862 & Littoral \\
\hline 6 & Alona quadrangularis & (O. F. Müller, 1785) & Littoral \\
\hline 7 & Alonella excisa & (Fischer, 1854) & Littoral \\
\hline 8 & Alonella exigua & (Lillijeborg, 1853) & Littoral \\
\hline 9 & Alonella nana & (Baird, 1843) & Littoral \\
\hline 10 & Chydorus sphaericus s.1 & (O. F. Müller, 1785) & Littoral \\
\hline 11 & Coronatella rectangula & (Sars, 1861) & Littoral \\
\hline 12 & Disparalona rostrata & (Koch, 1841) & Littoral \\
\hline 13 & Eurycercus (Eurycercus) lamellatus & (O. F. Müller, 1785) & Littoral \\
\hline 14 & Graptoleberis testudinaria & (Fischer, 1848) & Littoral \\
\hline 15 & Monospilus dispar & Sars. 1862 & Littoral \\
\hline 16 & Paralona pigra (formerly Chydorus piger) & (Sars. 1862) & Littoral \\
\hline 17 & Pleuroxus (Peracantha) trucatus & (O. F. Müller, 1785) & Littoral \\
\hline 18 & Pleuroxus (Pleuroxus) leavis & Sars. 1861 & Littoral \\
\hline 19 & Pleuroxus (Pleuroxus) uncinatus & Baird, 1850 & Littoral \\
\hline 20 & Pleuroxus (Pleuroxus) trigonellus & (O. F. Müller, 1776) & Littoral \\
\hline 21 & Pseudochydorus globosus (formerly Chydorus globosus) & (Baird, 1843) & Littoral \\
\hline 22 & Bosmina (Bosmina) longirostris & (O. F, Müller, 1785) & Pelagic \\
\hline 23 & Bosmina (Eubosmina) longispina group & Leydig, 1860 & Pelagic \\
\hline 24 & Bosmina (Eubosmina) coregoni group & Baird, 1857 & Pelagic \\
\hline 25 & Bythotrephes longimanus & Leydig, 1860 & Pelagic \\
\hline 26 & Camptocercus sp & Baird, 1843 & Pelagic \\
\hline 27 & Ceriodaphnia spp. & (Dana, 1853) & Pelagic \\
\hline 28 & Daphnia longispina group & O. F, Müller, 1785 & Pelagic \\
\hline 29 & Leptodora kindti & (Focke, 1844) & Pelagic \\
\hline
\end{tabular}

The Spearman correlation between Cladocera taxa densities outlined some positive and significant relations between the pelagic species (Table 2a). In particular, it is possible to notice a positive and significant correlation between $B$. coregoni and $B$. longispina and between $B$. coregoni and $D$. longispina. Both the latter species resulted to be positively correlated with the main predators $B$. longimanus and L. kindti. In addition, a positive and significant correlation was found between the littoral species $C$. sphaericus and the pelagic $B$. coregoni and $B$. longispina groups.

The Spearman correlation between Cladocera density and InSedRate pointed out positive and significant relationship between InSedRate and B. longirostris, $C$. sphaericus and the total littoral density, while negative relation existed between InSedRate and $B$. coregoni and L. kindti. Conversely, the organic matter content (LOI\%) had positive and significant relation with $B$. coregoni group, D. longispina, L. kindti and the total pelagic density (Table $2 b$ ).

Environmental variables

The mean air temperature from March to September has increased since the beginning of the twentieth century (Fig. 4a). In the first 20 years of the century (1900-1920), the average air temperature was $16 \pm 0.67{ }^{\circ} \mathrm{C}$, while it was $18 \pm 0.53{ }^{\circ} \mathrm{C}$ from 1990 to 2010. The Mann-Kendall test highlighted a 
Fig. 2 Depth profiles of subfossil Cladocera. "Number of Species": number of species identified in every layer; "Total Pelagic": total pelagic taxa density (ind/g dry weight); "Total Littoral": total littoral taxa density (ind/g dry weight); "Total": total Cladocera density (ind/g dry weight); "Pelagic \%": percentage of pelagic Cladocera over the Total. The horizontal lines identify the significant changing points pointed by the Pettitt test performed on the total pelagic densities

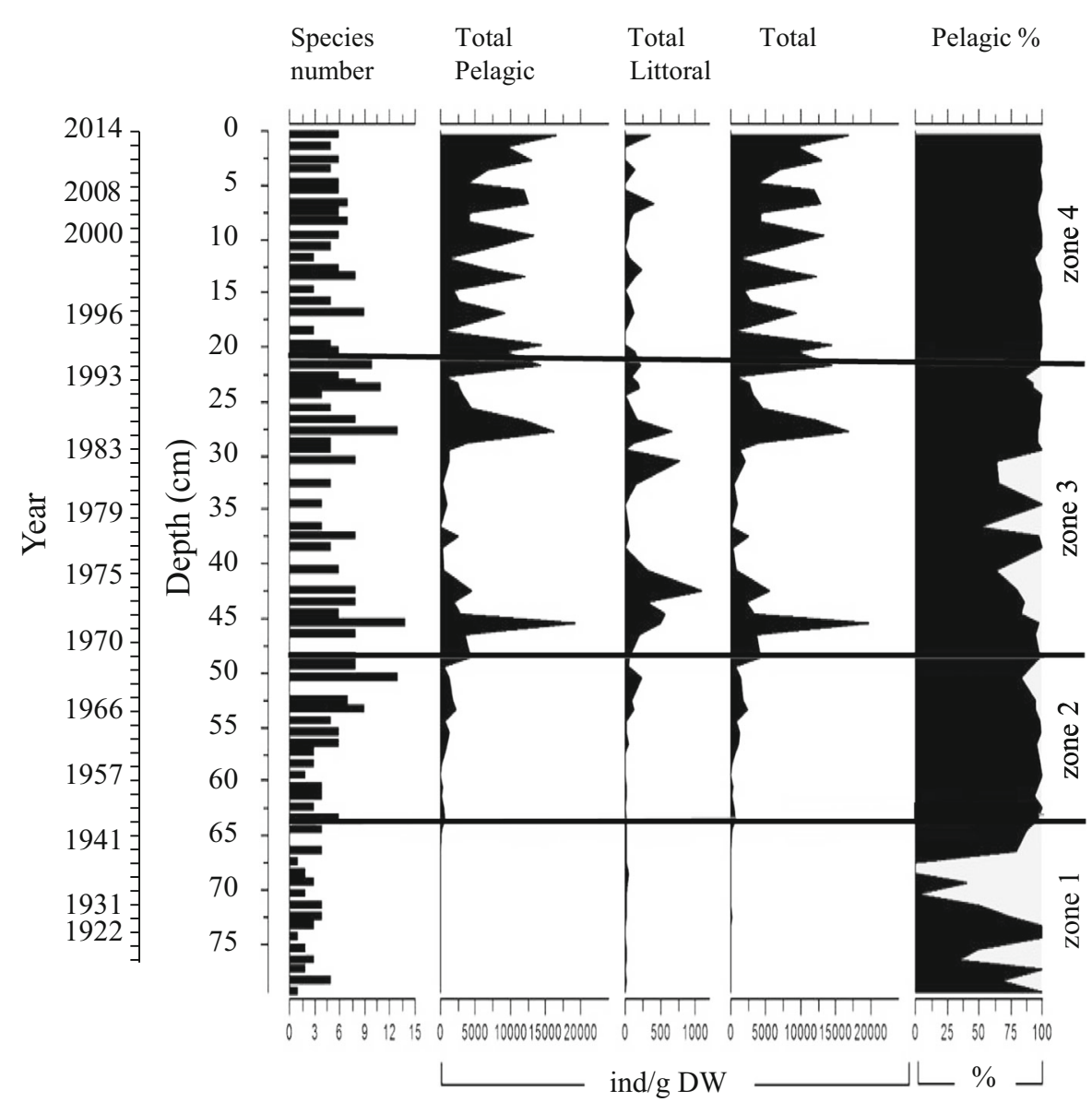

significant positive trend for temperature data ( $p$ value $<0.001$ ) at a rate of (Sen's slope) $0.022{ }^{\circ} \mathrm{C} /$ year (lower and upper bounds of the $95 \%$ trend's confidence interval equal to $0.017{ }^{\circ} \mathrm{C} /$ year and $0.026{ }^{\circ} \mathrm{C} /$ year), which is equivalent to $2.27{ }^{\circ} \mathrm{C}$ increase over the study period. Winter air temperatures (calculated from December to February) follow a similar pattern, with a significant positive trend (Mann-Kendall test, $p$ value $<0.001$; Fig. 4b). The rate of the increase was equal to $0.017{ }^{\circ} \mathrm{C} /$ year (lower and upper bounds of the $95 \%$ trend's confidence interval equal to $0.010{ }^{\circ} \mathrm{C} /$ year and $0.024{ }^{\circ} \mathrm{C} /$ year).

In addition, the average value of East Atlantic pattern from March to September and in winter (Fig. 4c and 4d) showed an increasing trend (MannKendall test, $p$ value $<0.001$ ), with a rate (Sen's slope) of $0.015 /$ year $(95 \% \mathrm{CI}[0.008,0.020])$ and 0.025/year (95\% CI[0.013, 0.036]), respectively. Since the second half of the 1990s, EA showed high inter-annual variability in particular in winter, spanning from - 1.64 in 2005 to 1.60 in 2014.

\section{Discussion}

Zooplankton plays a pivotal role in the biogeochemical cycles, and it is a key component transferring energy and matter from primary producers to higher trophic levels (Karpowicz et al. 2020). Small-bodied species, such as small cladocerans, are mainly regulated by the "bottom-up" process, while larger species are mostly regulated by "top-down" control by fish (Gliwicz 2003). Large-bodied zooplankters are more efficient at grazing on phytoplankton than their smaller competitors, which can only consume small particles. In the pelagial area of deep lakes, vertical environmental gradients (light, temperature, oxygen, food, predation pressure) prevail creating niches for different organisms (Karpowicz et al. 2019). Pelagic 


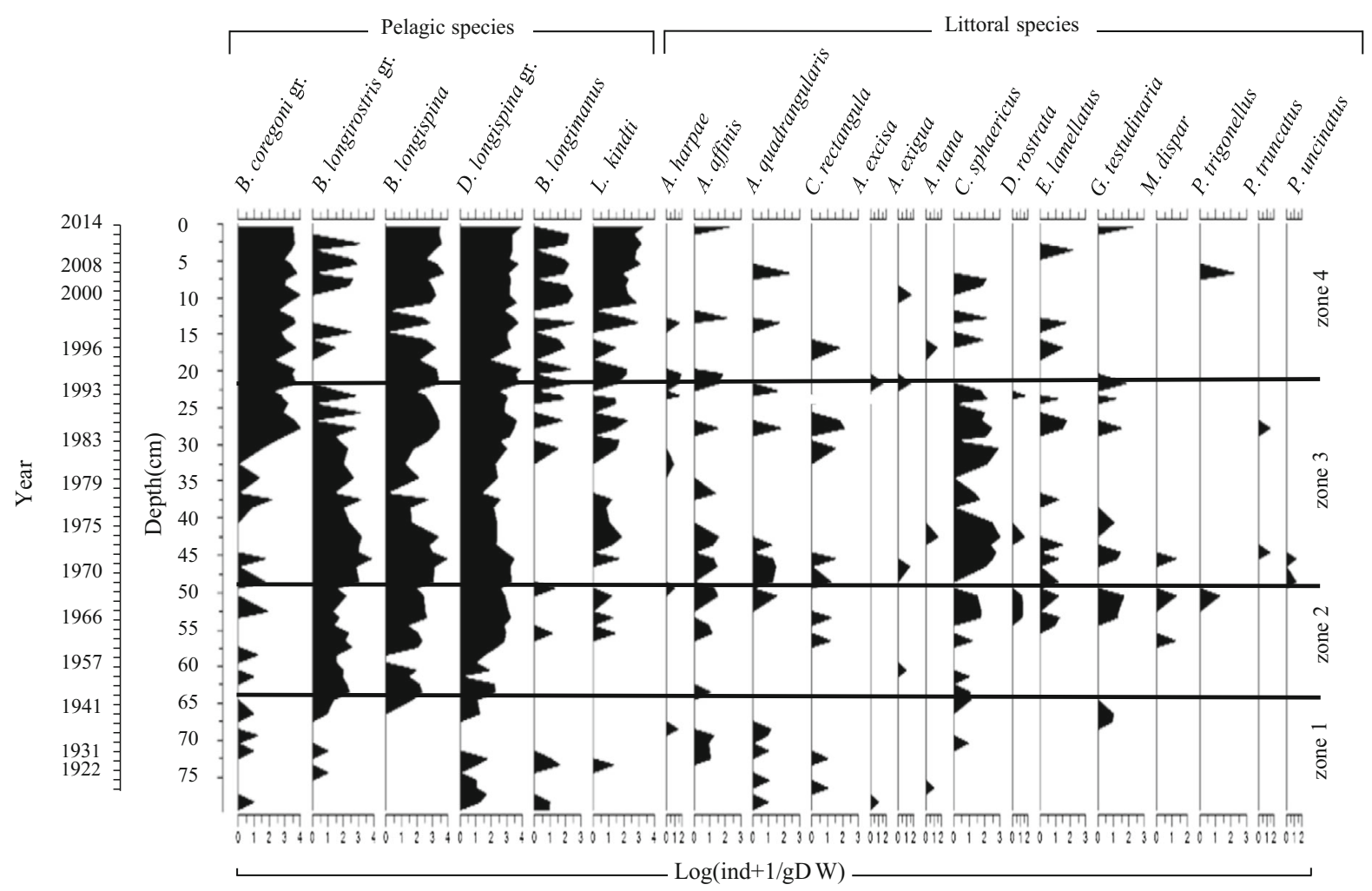

Fig. 3 Diagram of the density of the principal Cladocera species identified in the core collected from Lake Iseo sediments. Nine littoral and two pelagic species are not

zooplankton species richness and community structure is important for ecosystem functioning, food web complexity and ecosystem stability, and they are widely used as indicators of the ecological status of lakes (Pociecha et al. 2018; Karpowicz et al. 2019). Planktonic crustaceans, particularly the cladocerans, are highly sensitive to environmental changes and represent good sentinels to anthropic and climatic impacts (Berthon et al. 2014). The Cladocera remains detected in Lake Iseo sediment reflected the species composition and density of modern pelagic Cladocera assemblages (Leoni 2017; Leoni et al. 2018a), and this confirms the potential of these biological proxies for paleoecological reconstructions, as previously reported in several studies on different lake types (Milan et al. 2017; Pociecha et al. 2020). A relation between the principal pelagic species has been pointed out, highlighting that the density of predators, as $B$. longimanus and L. kindti, is related to the density of their principal prey, Bosminidae and D. longispina. These two species of predators are potentially represented in the diagram as they were detected in only one sediment level each and with scarce density. Cladocera full taxonomic names are reported in Table 1

competitor; however, in deep lakes, it has been verified that the coexistence of $B$. longimanus and $L$. kindti is possible thank to the temporal and spatial separation of their ecological niches, with shift in population seasonal cycles and vertical distribution on the water column (Manca et al. 2007; Manca 2011).

From the combined study of subfossil Cladocera remains, diatom-inferred total phosphorus, content of organic matter, inorganic sedimentation rate and some climate proxies (such as air temperature and East Atlantic pattern), we could identify several stages in the ecological evolution of Lake Iseo during the twentieth century. From the beginning of the twentieth century to the early 1960 s, Lake Iseo resulted characterized by low organic matter content and scarce density of Cladocera, with the prevalence of littoral species on the pelagic ones. The concentrations of phosphorus inferred by diatoms frustules $<30 \mu \mathrm{g} / \mathrm{L}$ suggest that Lake Iseo was in mesotrophic conditions in the beginning of the twentieth century. This contrasts with the oligotrophic original condition 
Table 2 Results of the correlation between (a) Cladocera species density and (b) the Cladocera and the organic content (LOI \%) and inorganic sedimentation rate (InSedRate) of each layer

\begin{tabular}{|c|c|c|}
\hline & & r-Spearman \\
\hline \multicolumn{3}{|l|}{ (a) } \\
\hline B. coregoni $\mathrm{gr}$ & B. longispina $\mathrm{gr}$ & $0.65 * * *$ \\
\hline B. coregoni $\mathrm{gr}$ & D. longispina $\mathrm{gr}$ & $0.74 * * *$ \\
\hline B. coregoni gr & B. longimanus & $0.51 * * *$ \\
\hline B. coregoni $\mathrm{gr}$ & L. kindi & $0.66 * * *$ \\
\hline B. longirostris & B. longispina $\mathrm{gr}$ & $0.3 *$ \\
\hline B. longirostris & C. sphaericus & $0.49 * * *$ \\
\hline B. longispina $\mathrm{gr}$ & D. longispina $\mathrm{gr}$ & $0.84 * * *$ \\
\hline B. longispina $\mathrm{gr}$ & B. longimanus & $0.36 * *$ \\
\hline B. longispina $\mathrm{gr}$ & L. kindi & $0.7 * * *$ \\
\hline B. longispina $\mathrm{gr}$ & C. sphaericus & $0.3 *$ \\
\hline D. longispina $\mathrm{gr}$ & B. longimanus & $0.45 * * *$ \\
\hline D. longispina $\mathrm{gr}$ & L. kindi & $0.73 * * *$ \\
\hline B. longimanus & L. kindi & $0.52 * * *$ \\
\hline \multicolumn{3}{|l|}{ (b) } \\
\hline InSedRate & B. coregoni gr & $-0.28^{*}$ \\
\hline InSedRate & B. longirostris & $0.29 *$ \\
\hline InSedRate & L. kindi & $-0.39 * *$ \\
\hline InSedRate & B. longimanus & $-0.24+$ \\
\hline InSedRate & C. sphaericus & $0.36 * *$ \\
\hline InSedRate & Total littoral & $0.36 * *$ \\
\hline LOI\% & B. coregoni gr & $0.46 * * *$ \\
\hline LOI\% & D. longispina $\mathrm{gr}$ & $0.29 *$ \\
\hline LOI\% & L. kindi & $0.29 *$ \\
\hline LOI\% & Total pelagic & $0.36 * *$ \\
\hline LOI\% & Total & $0.35 *$ \\
\hline
\end{tabular}

Only significant and marginally not significant relations are presented in the table: $* p$ value $<0.05$; $* * p$ value $<0.01$; $* * * p$ value $<0.001 ;+p$ value $<0.06$. The values that resulted significant after Bonferroni correction are presented in bold. Cladocera full taxonomic names are reported in Table 1

theorized for deep subalpine lakes (Ambrosetti et al. 1992; Tolotti et al. 2018). This may be due to the fact that the Swiss calibration set assigns a higher TP optimum to the taxon that was dominant in the deep core section $(C$. comensis) in comparison with the discarded calibration sets. Alternatively, it seems reasonable that Lake Iseo was not in oligotrophic in the early 1900s, similarly to what reconstructed for other more productive subalpine lakes exposed to intense early human impacts (Rapuc et al. 2019), such as Lake Lugano (Barbieri and Mosello 1992; Lepori et al. 2018). Nonetheless, it is relevant that the profile of diatom-inferred lake TP concentration agrees with both the pronounced increase in lake productivity since the postwar economic boom and with the increase in TP level since there.

In addition, that period was characterized by lower air temperature and EA value. East Atlantic pattern has been shown to drive climate patterns over the Mediterranean basin impacting on the limnological characteristics of deep subalpine lakes and on zooplanktonic communities (Manca et al. 2015; Leoni et al. 2018a). In particular, since negative and lower value of EA are associated with colder temperature in the Mediterranean region (Leoni et al. 2018a; Salmaso et al. 2018), the lower density of Cladocera in the deepest core layers can be also due to overall unfavorable conditions for the development of zooplankton community. Indeed, scarce food availability and lower winter air temperature are known to negatively affect lake primary productivity and zooplankton fecundity and growth rate (Zawisza and Szeroczyńska 2007; Manca et al. 2015). This result is consistent with those found in other studies on deep subalpine lakes, where the deepest layers are characterized by low species diversity and density (Milan et al. 2015). From the beginning of the 1960s, diatominferred phosphorus concentrations began to increase. The increasing trend is confirmed by several studies that observed a period of strong eutrophication affecting the principal deep subalpine lakes, including Lake Iseo (Rogora et al. 2018). Cladocera community seems to react to the higher nutrient availability; indeed, a progressive increase of planktonic species densities and richness, indicators of warm and nutrient-rich water, was observed. In this phase, species such as B. longirostris, B. longispina and D. longispina became dominant. In particular, $B$. longirostris is considered as a typical indicator of eutrophication (Zawiska et al. 2014; Milan et al. 2017). The increase of pelagic taxa in times of high nutrient availability was an expected result following the bottom-up mechanisms reported in the literature and verified in other lakes (McQueen et al. 1989). In deep lakes, phosphorus availability controls the density and the composition of the phytoplankton community, affecting food availability and quality for primary consumers. A higher biomass of zooplankton, due to high 

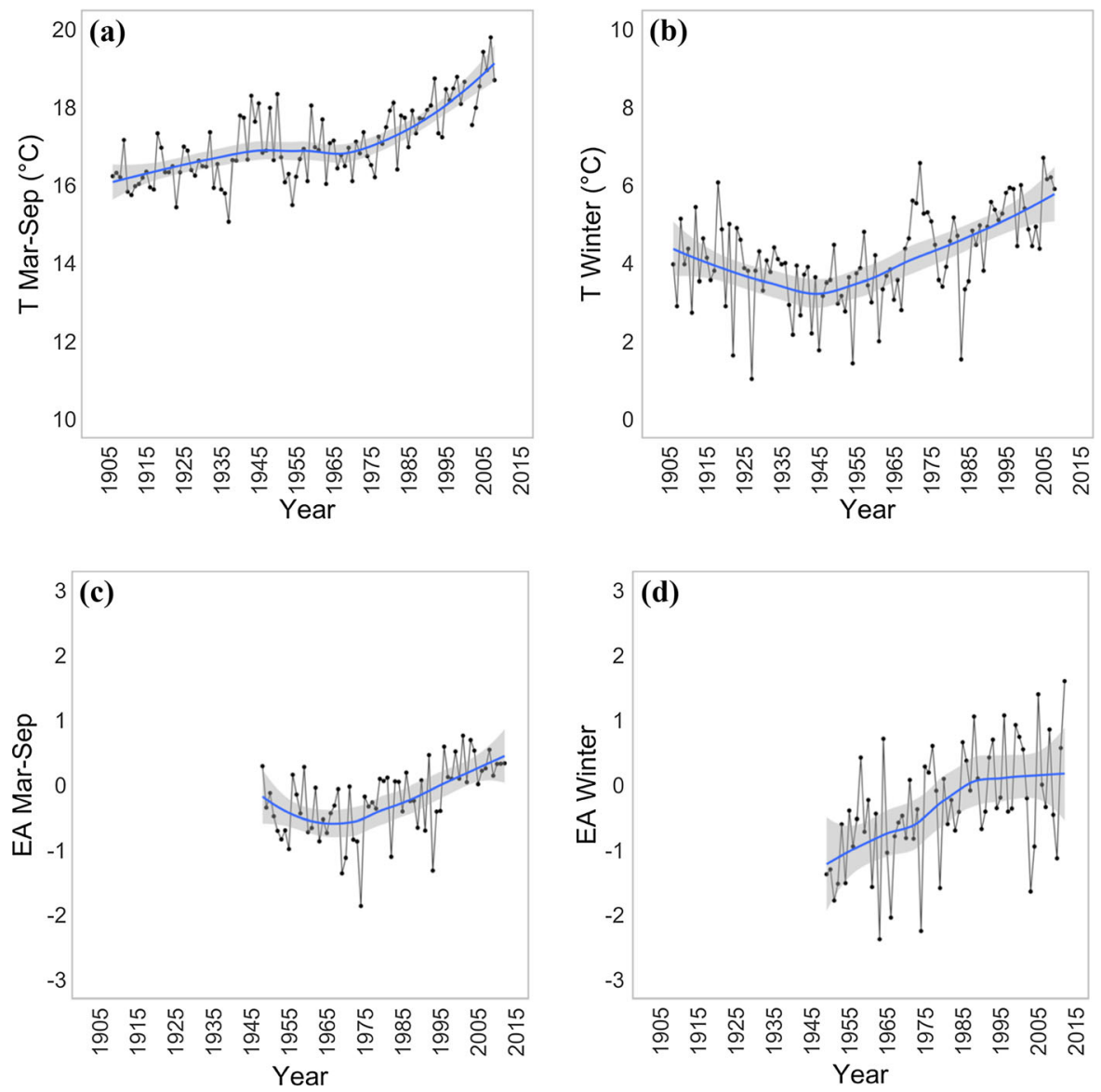

Fig. 4 Temporal trend of climatic proxies: a Air temperature from March to September $\left(\mathrm{T}_{\mathrm{MAR}-\mathrm{SEP}}\right)$. b Winter air temperature, from December to February $\left(\mathrm{T}_{\text {WINTER }}\right)$. c East Atlantic pattern from March to September (EA

phosphorus concentration, is usually associated with higher biomass of primary producers (Leoni et al. 2014; Manca et al. 2015). Furthermore, the importance of food quality (i.e., presence of certain phytoplankton taxa, diatoms, and green algae), in particular for planktonic taxa with relatively high $P$ requirements, is well supported in the literature (Gulati and DeMott 1997; Weers and Gulati 1997). The increase in the density of primary consumers is known to positively affect their predators, and this triggers the entire pelagic food web through a bottom-up mechanism (primary producers).

The massive presence of $B$. longirostris group reversed at the end of the 1980s, when the most abundant species of Bosminidae became B. coregoni group that required less eutrophic but warmer waters (Stenson 1976). In this phase, inferred total

pattern, from December to February $\left(\mathrm{EA}_{\text {WINTER }}\right)$. Blue curves indicate the LOESS smoothing and gray area the confidence interval (95\%) around smooth. (Color figure online)

phosphorus decreases but it is possible to observe an increase in air temperature and in EA values, corresponding to warmer climate. We hypothesize that the warmer climate combined with the reduced phosphorus concentration favored the development of $B$. coregoni instead of $B$. longirostris. It is known that most of the subalpine lakes, after the strong phases of eutrophication that peaked between 1960 and 1980s, faced a phase of re-oligotrophication. However, in Lake Iseo the process was not so marked and the lake is still in meso-eutrophic condition (Leoni et al. 2018a; Rogora et al. 2018), despite the partial reduction of epilimnetic phosphorus concentration. Indeed, from the second half of 1980s the first measures to reduce nutrient loading to freshwater were taken, like, for instance, the development of the first wastewater collectors and treatment plants (Garibaldi et al. 1999). 
Another factor that contributed to the partial reduction of the spring phosphorus concentration after the 1980s is the decrease of the late winter vertical mixing depth. Indeed, a reduction in the depth reached by water turnover in late winter, connected with the increase in winter air and water temperature, has been observed in all the subalpine lakes. In deep oligomictic lake, as Lake Iseo, water turnover in late winter represents a key factor in determining spring phosphorus concentration in the epilimnetic layers, because it favors the vertical transfer from the hypolimnion and the replenishment of phosphorus in the epilimnion, while shallow mixing has the opposite effect (Leoni et al. 2018b; Rogora et al. 2018).

A generalized increase in all the pelagic species (including the predators L. kindti and B. longimanus) was observed in the upper layers of the core concomitantly with the increased density of $B$. coregoni group. This can be due to the increased water temperatures related to the warmer climate, as suggested by the air temperature trend and East Atlantic pattern. Moreover, several recent studies reported increases in water temperature, and in particular, Pareeth et al. (2017) reported an increase in surface water temperature of $0.017{ }^{\circ} \mathrm{C} /$ year in the last 30 years (1986-2015). This period corresponded to the highest density and the major species variability recorded in Lake Iseo sediment core, and the cooccurrence of not limited phosphorus concentration and warmer water favored the development of lake primary and secondary production (Schalau et al. 2008). As verified in other deep lakes, higher temperature positively influenced the development of zooplanktonic and phytoplanktonic organisms, their primary food resource, in some cases miming the effects of eutrophication (Lepori et al. 2018).

Interestingly, in Lake Iseo the total cladoceran density along the core showed pronounced oscillations, with alternating phases of high density to phases of very low density, in particular of the pelagic species. Lake Iseo is characterized by a high sedimentation rate, in particular if compared to other deep subalpine lakes like, for instance, Lake Garda. As a consequence, the 80-cm-long sediment core retrieved from Lake Iseo covers around 100 years, while a shorter core $(48 \mathrm{~cm})$ collected from Lake Garda covered around seven centuries according to the radiocarbon dating, with the bottom layer dating back at $1418 \pm 30 \mathrm{AD}$ (Milan et al. 2015). The high sedimentation rate points out the strong impact that catchment area dynamics can have on lake ecological characteristics. A pattern similar to that of Lake Iseo, with periods of high density alternated to strong decreases in pelagic taxa density, was detected by Milan et al. (2016) in Lake Ledro. In this lake, characterized by a high ratio between catchment area and surface area as Lake Iseo, these shifts could be imputed to the effect of hydrological variability and in particular to flood events. In Lake Iseo, a similar hypothesis can be plausible (Rapuc et al. 2019) and high amounts of inorganic material coming from the catchment area through flood events can negatively affect lake production increasing water turbidity and nutrient availability and leading to unfavorable conditions for pelagic community development (Adrian et al. 2009). Indeed, in Lake Iseo it was possible to observe a negative correlation between the inorganic sedimentation rate and some vulnerable pelagic species as B. coregoni and $L$. kindti. Moreover, the littoral species $C$. sphaericus and the high adaptable $B$. longirostris (Milan et al. 2017) increased in phases characterized by high sedimentation rate. This relation can be due to a major material transportation from the littoral zone to the centre of the lake, caused by high hydrological variability in the catchment area. An increase in sediment resuspension, due to the increase of inorganic material input, may increase water turbidity and negatively affect lake primary production (Graham and Vinebrooke 2009; Morabito et al. 2018) and promote detritivorous taxa development. However, we cannot exclude that periodical floods could directly transport littoral species and Cladocera remains in the pelagic zone.

In the current context of global climate changes, the intensification of catastrophic events, such as floods, is expected in European regions and mountainous areas (Hirabayashi et al. 2013) and the study of these extreme events represents a great issue for natural hazards assessment, water resources management and freshwater ecosystem services protection. However, tendencies at the regional and local scales are still uncertain, and the use of geological paleoclimate records associated with paleobiological information can be useful tools to develop for understanding the past variations of these events in contrasting climatic contexts and forecast future scenarios. 


\section{Conclusions}

The present paleolimnological investigation of Lake Iseo allowed identifying some environmental factors that likely played a key role in driving the changes in the structure and composition of pelagic zooplankton during the last century. In particular, the results suggest that climatic factors should be considered together with nutrient availability as key factors in controlling the temporal development of plankton communities and pelagic food web structure. In the period characterized by stable trophic condition and not-limiting nutrient level, climatic variation, and in particular increased temperature, became the most important driver of lake ecological characteristics. Moreover, this study provides the basis for understanding the combined effect of climate and eutrophication over deep lake ecosystems and to interpret possible future changes.

Acknowledgements We would like to thank the collaborators and students who have contributed to the collection of historical data series. Investigations were partly carried out in the framework of the LTER (Long-Term Ecological Research) Italian network, site Southern Alpine lakes, IT08-000-A (http:// www.Iteritalia.it/). Research activities on Lake Iseo have been funded by University of Milano-Bicocca (FA grant) and supported by national and regional grants and institutional funds. The dating of the core and the diatom analyses were financially supported by the Fondazione Edmund Mach (FEM).

Funding Open access funding provided by Università degli Studi di Milano - Bicocca within the CRUI-CARE Agreement.

Open Access This article is licensed under a Creative Commons Attribution 4.0 International License, which permits use, sharing, adaptation, distribution and reproduction in any medium or format, as long as you give appropriate credit to the original author(s) and the source, provide a link to the Creative Commons licence, and indicate if changes were made. The images or other third party material in this article are included in the article's Creative Commons licence, unless indicated otherwise in a credit line to the material. If material is not included in the article's Creative Commons licence and your intended use is not permitted by statutory regulation or exceeds the permitted use, you will need to obtain permission directly from the copyright holder. To view a copy of this licence, visit http://creativecommons.org/licenses/by/4.0/.

\section{References}

Adrian R, O'Reilly CM, Zagarese H, Baines SB, Hessen DO, Keller W et al (2009) Lakes as sentinels of climate change.
Limnol Oceanogr 54:2283-2297. https://doi.org/10.4319/ lo.2009.54.6_part_2.2283

Alric B, Jenny JP, Berthon V, Arnaud F, Pignol C, Reyss JL, Sabatier P, Perga MTE (2013) Local forcings affect zooplankton responses to climate warming. Ecology 94:2767-2780

Ambrosetti W, Barbanti L, Mosello R, Pugnetti A (1992) Limnological studies on the deep southern Alpine lakes Maggiore, Lugano, Como, Iseo and Garda. Mem Ist ital Idrobiol 50:117-146

Appleby PG (2005) Chronostratigraphic techniques in recent sediments. In: Last WM, Smol JP (eds) Tracking environmental change using lake sediments. Kluwer Academic Publishers, pp 171-203

Auer I, Böhm R, Jurkovic A, Lipa W, Orlik A, Potzmann R et al (2007) HISTALP — historical instrumental climatological surface time series of the greater Alpine region 1760-2003. Int J Climatol 27:17-46

Barbieri A, Mosello R (1992) Chemistry and trophic evolution of Lake Lugano in relation to nutrient budget. Aquat Sci 54:219-237

Battarbee RW, Jones VJ, Flower RJ, Cameron NG, Bennion H, Carvalho L et al (2001) Diatoms. In: Last WM, Smol JP (eds) Tracking environmental change using lake sediments. Kluwer Academic Publishers, Dordrecht, pp 155-202

Battarbee RW, Anderson NJ, Bennion H, Simpson GL (2012) Combining limnological and palaeolimnological data to disentangle the effects of nutrient pollution and climate change on lake ecosystems: Problems and potential. Freshw Biol 57:2091-2106. https://doi.org/10.1111/j. 1365-2427.2012.02860.x

Berthon V, Alric B, Rimet F, Perga MTE (2014) Sensitivity and responses of diatoms to climate warming in lakes heavily influenced by humans. Freshw Biol 59:1755-1767

Caballero M, Zawisza E, Hernández M, Lozano-García S, RuizCórdova JP, Waters MN, Ortega Guerrero B (2020) The Holocene history of a tropical high-altitude lake in central Mexico. The Holocene 30(6):865-877. https://doi.org/10. 1177/0959683620902226

Cheng L, Xue B, Zawisza E, Yao S, Liu J, Lingling L (2020) Effects of environmental change on subfossil Cladocera in the subtropical shallow freshwater East Taihu Lake. China Catena 188:104446. https://doi.org/10.1016/j.catena.2019. 104446

Frey D (1986) Cladocera analysis. In: Berglund BE (ed) Handbook of holocene palaeoecology and palaeohydrology. Citeseer, pp 677-692

Garibaldi L, Mezzanotte V, Brizzio MC, Rogora M, Mosello R (1999) The trophic evolution of Lake Iseo as related to its holomixis. J Limnol 58:10-19. https://doi.org/10.4081/ jlimnol.1999.10

Garibaldi L, Anzani A, Marieni A, Leoni B, Mosello R (2003) Studies on the phytoplankton of the deep subalpine Lake Iseo. J Limnol 62:177-189. https://doi.org/10.4081/ jlimnol.2003.177

Gliwicz Z (2003) Between hazards of starvation and risk of predation: the ecology of off-shore animals. 414 International Ecology Institute: Oldendorf (Luhe), Germany, 2003. ISBN 978-3-946729-12-9 
Graham M, Vinebrooke RD (2009) Extreme weather events alter planktonic communities in boreal lakes. Limnol Oceanogr. https://doi.org/10.4319/lo.2009.54.6_part_2. 2481

Gulati RD, DeMott WR (1997) The role of food quality for zooplankton: remarks on the state-of-the-art, perspectives, and priorities. Freshw Biol 38:753-768

Heiri O, Lotter AF, Lemcke G (2001) Loss on ignition as a method for estimating organic and carbonate content in sediments: reproducibility and comparability of results. J Paleolimnol 25:101-110. https://doi.org/10.1023/A: 1008119611481

Hirabayashi Y, Mahendran R, Koirala S et al (2013) Global flood risk under climate change. Nature Climate Change 3:816-821. https://doi.org/10.1038/nclimate1911

Juggins S (2007) C2. Software for ecological and palaeoecological data analysis and visualisation. User guide Version 1.5. Newcastle University, Newcastle upon Tyne

Karpowicz M, Ejsmont-Karabin J, Więcko A, Górniak A, Cudowski A (2019) A place in space-the horizontal vs vertical factors that influence zooplankton (Rotifera, Crustacea) communities in a mesotrophic lake. J. Limnol. 78(2):243-258. https://doi.org/10.4081/jlimnol.2019.1886

Karpowicz M, Zieliński P, Grabowska M, Ejsmont-Karabin J, Kozłowska J, Feniova I (2020) Effect of eutrophication and humification on nutrient cycles and transfer efficiency of matter in the freshwater food web. Hydrobiologia 847(11):2521-2540. https://doi.org/10.1007/s10750-02004271-5

Leoni B (2017) Zooplankton predators and prey: Body size and stable isotope to investigate the pelagic food web in a deep lake (Lake Iseo, Northern Italy). J. Limnol. 76:85-93. https://doi.org/10.4081/jlimnol.2016.1490

Leoni B, Marti CL, Imberger J, Garibaldi L (2014) Summer spatial variations in phytoplankton composition and biomass in surface waters of a warm-temperate, deep, oligoholomictic lake: Lake Iseo, Italy. Inland Waters 4:303-310. https://doi.org/10.5268/IW-4.3.569

Leoni B, Nava V, Patelli M (2018a) Relationships among climate variability, Cladocera phenology and the pelagic food web in deep lakes in different trophic states. Mar Freshw Res 69:1534. https://doi.org/10.1071/mf17243

Leoni B, Patelli M, Soler V, Nava V (2018b) Ammonium transformation in 14 lakes along a trophic gradient. Water (Switzerland). https://doi.org/10.3390/w10030265

Leoni B, Spreafico M, Patelli M, Soler V, Garibaldi L, Nava V (2019) Long- term studies for evaluating the impacts of natural and anthropic stressors on limnological features and the ecosystem quality of Lake Iseo. Adv Oceanogr Limnol. https://doi.org/10.4081/aiol.2019.8622

Lepori F, Roberts JJ, Schmidt TS (2018) A paradox of warming in a deep peri-Alpine lake (Lake Lugano, Switzerland and Italy). Hydrobiologia 824:215-228. https://doi.org/10. 1007/s10750-018-3649-1

Lotter AF, Birks HJB, Hofmann W, Marchetto A (1998) Modern diatom, cladocera, chironomid, and chrysophyte cyst assemblages as quantitative indicators for the reconstruction of past environmental conditions in the Alps. II. Nutr J Paleolimnol 19:443-463

Mallakpour I, Villarini G (2016) A simulation study to examine the sensitivity of the Pettitt test to detect abrupt changes in mean. Hydrol Sci J 61:245-254. https://doi.org/10.1080/ 02626667.2015 .1008482

Manca M (2011) Invasions and re-emergences: An analysis of the success of Bythotrephes in Lago Maggiore (Italy). J Limnol 70:76-82. https://doi.org/10.3274/JL11-70-1-10

Manca MM, Portogallo M, Brown ME (2007) Shifts in phenology of Bythotrephes longimanus and its modern success in Lake Maggiore as a result of changes in climate and trophy. J Plankton Res 29:515-525. https://doi.org/10. 1093/plankt/fbm033

Manca M, Rogora M, Salmaso N (2015) Inter-annual climate variability and zooplankton: Applying teleconnection indices to two deep subalpine lakes in Italy. J Limnol 74:123-132. https://doi.org/10.4081/jlimnol.2015.1014

McQueen DJ, Johannes MRS, Post JR, Stewart TJ, Lean DRS (1989) Bottom-up and top- down impacts on freshwater pelagic community structure. Ecol Monogr 59:289-309. https://doi.org/10.2307/1942603

Milan M, Bigler C, Salmaso N, Guella G, Tolotti M (2015) Multiproxy reconstruction of a large and deep subalpine lake's ecological history since the Middle Ages. J Great Lakes Res 41:982-994. https://doi.org/10.1016/j.jglr.2015. 08.008

Milan M, Bindler R, Tolotti M (2016) Combining sediment Cladocera remains and geochemistry to reveal the role of a large catchment in driving changes in a small subalpine lake (Lake Ledro, N-Italy). Adv Oceanogr Limnol. https:// doi.org/10.4081/aiol.2016.6399

Milan M, Bigler C, Tolotti M, Szeroczyńska K (2017) Effects of long-term nutrient and climate variability on subfossil Cladocera in a deep, subalpine lake (Lake Garda, northern Italy). J Paleolimnol 58:335-351. https://doi.org/10.1007/ s10933-017-9981-z

Milecka K, Mirosław-Grabowska J, Zawisza E, Kowalewski G (2020) Susceptibility of small boreal lakes to environmental changes as inferred from organic sediments of Lake Talvilampi (Finland). The Holocene 30(3):458-473. https://doi.org/10.1177/0959683619887432

Morabito G, Mazzocchi MG, Salmaso N, Zingone A, Bergami C et al (2018) Plankton dynamics across the freshwater, transitional and marine research sites of the LTER-Italy Network. Patterns, fluctuations, drivers. Sci Total Environ 627:373-387. https://doi.org/10.1016/j.scitotenv.2018.01. 153

Nakagawa S (2004) A farewell to Bonferroni: the problems of low statistical power and publication bias. Behav Ecol 15:1044-1045. https://doi.org/10.1093/beheco/arh107

Nava V, Patelli M, Soler V, Leoni B (2017) Interspecific relationship and ecological requirements of two potentially harmful cyanobacteria in a deep South-Alpine Lake (L. Iseo, I). Water 9:993. https://doi.org/10.3390/w912099

Pareeth S, Bresciani M, Buzzi F, Leoni B, Lepori F, Ludovisi A, Morabito G, Adrian R, Neteler M, Salmaso N (2017) Warming trends of perialpine lakes from homogenised time series of historical satellite and in-situ data. Sci Total Environ 578:417-426. https://doi.org/10.1016/j.scitotenv. 2016.10.199

Perga MTE, Frossard V, Jenny JP, Alric B, Arnaud F, Berthon V et al (2015) High-resolution paleolimnology opens new management perspectives for lakes adaptation to climate 
warming. Front Ecol Evol 3:72. https://doi.org/10.3389/ fevo.2015.00072

Pociecha A, Bielańska-Grajner I, Kuciel H, Wojtal AZ (2018) Is zooplankton an indicator of the water trophic level in dam reservoirs? Oceanol Hydrobiol Stud 47(3):288-295. https://doi.org/10.1515/ohs-2018-0027

Pociecha A, Wojtal AZ, Szarek-Gwiazda E, Cieplok A, Ciszewski D, Cichoń S (2020) Neo-and paleo-limnological studies on diatom and cladoceran communities of subsidence ponds affected by mine waters (S. Poland). Water 12(6):1581. https://doi.org/10.3390/w12061581

Rapuc W, Sabatier P, Arnaud F, Palumbo A, Develle AL, Reyss JL, Augustin L, Edouard Régnier E, Piccin A, Chapron E, Dumoulin JP, von Grafenstein U (2019) Holocene-long record of flood frequency in the Southern Alps (Lake Iseo, Italy) under human and climate forcing. Global Planet Change 175:160-172. https://doi.org/10.1016/j.gloplacha. 2019.02.010

Rice WR (1989) Analyzing tables of statistical tests. Evolution 43:223-225

Rogora M, Buzzi F, Dresti C, Leoni B, Lepori F, Mosello R et al (2018) Climatic effects on vertical mixing and deep-water oxygen content in the subalpine lakes in Italy. Hydrobiologia 824:33-50. https://doi.org/10.1007/s10750-0183623-y

Salmaso N, Anneville O, Straile D, Viaroli P (2018) European large perialpine lakes under anthropogenic pressures and climate change: present status, research gaps and future challenges. Hydrobiologia 824:1-32. https://doi.org/10. 1007/s107500183758x

Schalau K, Rinke K, Straile D, Peeters F (2008) Temperature is the key factor explaining interannual variability of Daphnia development in spring: a modelling study. Oecologia 157(3):531-543. https://doi.org/10.1007/s00442-0081081-3

Stenson JAE (1976) Significance of predator influence on composition of Bosmina spp. populations. Limnol Oceanogr 21:814-822. https://doi.org/10.4319/lo.1976.21.6. 0814
Szeroczyńska K, Sarmaja-Korjonen K (2007) Atlas of subfossil Cladocera from Central and Northern Europe. Friends of the Lower Vistula Society, Swiecie: 84

Szeroczyńska K, Santhanam P, Begum A, Pachiappan P, ChenWishart M, Błędzki LA et al (2007) Atlas of subfossil Cladocera from Central and Northern Europe. Basic Appl Zooplankton Biol 37:e7-e8. https://doi.org/10.1007/9781-4939-3447-8_6

Tolotti M, Milan M, Szeroczyńska K (2016) Subfossil Cladocera as a powerful tool for paleoecological reconstruction. Adv Oceanogr Limnol 7:125-130. https://doi.org/10.4081/ aiol.2016.6467

Tolotti M, Dubois N, Milan M, Perga ME, Straile D, Lami A (2018) Large and deep perialpine lakes: a paleolimnological perspective for the advance of ecosystem science. Hydrobiologia 824:291-321. https://doi.org/10.1007/ s10750-018-3677-x

Vadadi-Fülöp C, Hufnagel L (2014) Climate change and plankton phenology in freshwater: current trends and future commitments. J Limnol 73:1-16. https://doi.org/10.4081/ jlimnol.2014.770

Weers PMM, Gulati RD (1997) Growth and reproduction of Daphnia galeata in response to changes in fatty acids, phosphorus, and nitrogen in Chlamydomonas reinhardtii. Limnol Oceanogr 42:1584-1589

Zawiska I, Słowiński M, Correa-Metrio A, Obremska M, Luoto $T$, Nevalainen L et al (2014) The response of a shallow lake and its catchment to Late Glacial climate changes-a case study from eastern Poland. CATENA 126:1-10. https:// doi.org/10.1016/j.catena.2014.10.007

Zawisza E, Szeroczyńska K (2007) The development history of Wigry lake as shown by subfossil Cladocera. Geochronometria 27:67-74. https://doi.org/10.2478/ v10003-007-00

Publisher's Note Springer Nature remains neutral with regard to jurisdictional claims in published maps and institutional affiliations. 